\title{
Why prison? Posing the question
}

\author{
David Scott
}

The question why prison? has never been more pertinent or compelling than it is today. Rates of penal incarceration in many countries around the world have reached record levels and the combined world prison population recently surpassed Ten Million. ${ }^{1}$ When such enormous figures are presented to us it can be difficult to conceptualise what the data actually means, but if all the people imprisoned in just three nations - the United States of America (USA), China and Russia - were to stand next to each other the resulting line would stretch across the surface of the planet. Notwithstanding a few notable exceptions the global data are clear and decisive: penal incarceration has risen and continues to rise at an alarmingly fast pace (Walmsley, 2012). For Dario Melossi (2011:50) global penal excess at the beginning of the twenty-first century is tantamount to a "great internment". Such phraseology immediately brings to mind a possible connection between the current penal incarceration binge and the emergence of the great confinement in the late sixteenth and early seventeenth centuries (Rusche and Kirchheimer, 1939/2003; Foucault, 1967). It also begs parallels with the emergence in the eighteenth century of a centralised bureaucratic state with the mandate to manage rising economic inequality and manifestations of class struggle. The mission of the new sites of state detention was unequivocal: to survey, classify, regulate and control unwanted and unwelcome populations (Rothman, 1971; Foucault, 1977; Ignatieff, 1978; Melossi and Pavarini, 1981; Cohen, 1985; Scull, 1993). As Thomas Mathiesen (1990:14, emphasis in original) maintained some twenty or more years ago, the rapid and spectacular growth of penal incarceration since the early 1970s may indicate a new third stage in the development of imprisonment, this time in response to a perceived 'need for discipline in given segments and groups of the population'. Perhaps then we should not be surprised that prisons everywhere are bursting at the seams with the poor, marginalised and socially deprived.

\footnotetext{
${ }^{1}$ Due to categorisation and recording problems even this figure is likely to be an underestimate. For example, it is estimated that there are more than 650,000 people in detention centres in China. If this data is included the overall total for China is 2.3 million and the world total 10.75 million (Walmsley, 2012:1)
} 
Asking the question why prison? connects contemporary critical analysis of penal incarceration with an enquiry that has been the attention of some of the greatest thinkers on the 'confinement project' in the past and provides the central premise of this edited collection. This introductory chapter is divided into three parts. The section directly below explores data from twelve countries to update and evidence Thomas Mathiesen's (1990) argument regarding the emergence of a third stage of penal incarceration. The discussion then moves on to critically evaluate five of the main 'common sense' justifications proposed in defence of the prison. Finding such justifications unconvincing it is maintained that the global explosion in the use of imprisonment in the last four decades has more to do with its role in the control of certain identifiable groups of people rather than as a rational response to 'crime'. The introduction closes with a brief summary of the following fourteen chapters by some of the leading contemporary writers on imprisonment.

\section{Global hyper-incarceration}

Even the most cursory glance at Table 1, which details penal incarceration rates in twelve countries since 1970, can leave no doubt about current trends in the Western World. In ten of the twelve nations, which are either predominantly English speaking or located in Europe, the prisoner rate has increased in the last forty years. In one country, Germany, the prisoner rate rose in the late twentieth century but by 2010 had returned to virtually the same level as 1970. Only in Finland can we find evidence of a clear downward trend. This deviant case has attracted considerable academic attention (Lappi-Seppala, 2012) and it is worth noting that whilst in 1970 Finland had a prisoner rate second only to the USA, by 2010 it had by far the lowest recorded rate of the twelve selected countries. Let us take this analysis of prisoner rates further by first considering in some depth the USA and then moving on to reflect upon the situation in four other Anglophone countries before concluding this overview with an account of the seven other selected countries in Europe, paying particular attention to the recently debated notion of 'Nordic exceptionalism'.

<insert Table 1 near here> 
The USA today stands at the top of the world penal incarceration rate. It was not always so. For most of the twentieth century until the mid 1970s the USA had a relatively stable rate of penal incarceration, remaining well below 200 per 100,000 of the national population. ${ }^{2}$ In 1970 the Average Daily Population (ADP) of those confined in prison or jail was 250,000 people, ${ }^{3}$ yet the rise since this time has been quite staggering. By the early 1980s the USA prisoner ADP had doubled to more than 500,000 prisoners and by February 2000 this number had surpassed 2 million (Lacey, 2011). In 2010 the USA imprisoned 2.3 million people at a rate of 748 per 100,000 and 7.3 million people, or 1 in 33 adults were either in prison, on parole or on probation. Prisoner rates in the USA are now five times greater than those of Western European and English speaking countries. ${ }^{4}$

Whilst politicians in the USA have recently raised concerns about the financial costs of imprisonment - the USA spent $\$ 47$ billion on prisons in 2008 - penologists have primarily focused on the social dimensions of penal incarceration. The phenomenal rise in the USA prison population has been described as 'mass imprisonment' for much of the last decade (Garland, 2001a). Recently however Loïc Wacquant (2010a) has argued that this term is inappropriate as penal excess has not been experienced by the 'mass' of the populace but almost exclusively by poor Black, Latino, and Hispanic Americans. USA prison data supports his assertion. Whilst more than 1 in 100 American adults are in prison, the figure is 1 in 50 for Hispanic men and 1 in 20 for Black men. The overall penal incarceration rate for men in the USA is 943 per 100,000 . When analysed via categorisations of 'race' the rate falls to 487 for white men but rises to 1,261 for Hispanic and Latino men and 3,042 for Black men (Lacey, 2011). African Americans make up 13 per cent of the general population but 60 per cent of the USA prison population and are eight times more likely to be incarcerated than whites (Downes, 2012). The centrality of class should not be forgotten here. Middle-class Black populations are likely to have benefited from hyper-incarceration. By some estimates the probability of middle class African Americans going to prison dropped by $50 \%$ in the last 20 years (Wacquant,

\footnotetext{
${ }^{2}$ I will subsequently just refer to the figure 100,000 .

${ }^{3}$ There is some debate over the accuracy of this number, with one commentator pointing to the figure of 380,000 prisoners in the USA at this time (Wacquant, 2009).

${ }^{4}$ It should be noted that this USA data does not include juveniles and persons in police lockups, a figure which Loïc Wacquant (2009) estimates at around 140,000 people.
} 
2001; 2010a). This being said, more African Americans are today under correctional supervision than were enslaved during the antebellum period (Alexander, 2011). Loïc Wacquant (2010a) refers to this phenomenon as 'hyper-incarceration', indicating the existence of 'penal excess' (Pratt, 2008b) without obfuscating its real target: poor and Black or Minority Ethnic (BME) populations. The contention of this chapter is that such 'hyper-incarceration' also has a global dimension (Davis, 2012).

In other Anglophone countries we can also find evidence of escalating prisoner populations and an intensification in the discipline and control of BME populations from the poorest segments of the working class. In New Zealand in the 1960s the prisoner ADP was around 1,700 and although it remained relatively stable until the mid-1980s, from this point the prisoner rate rose from 80 per 100,000 to 126 per 100,000 in 1996 (Cavadino and Dignan, 2006). It increased still further to 199 per 100,000 in 2010 and in March 2011 the prisoner ADP peaked at 8,844. Like the USA, when prisoner rates are examined through the lens of 'race', disturbing patterns emerge. Maori men constitute 15 per cent of the national population but account for 51 per cent of the male prisoner population. They are eight times more likely to be imprisoned than non-Maori men by New Zealand criminal processes. In Australia there has been a steady rise in prisoner populations since the 1970s and by March 2012 it had a prisoner rate of 133 per 100,000 and a prisoner ADP of 29,226. Two of the most striking aspects of Australian prison populations are the divergences between different territories and the overpenalisation of Aboriginal and Torres Strait Islanders. In March 2012 The Northern Territory had a prisoner rate of 821 per 100,000 , which if it was nation in its own right would be the number one penal incarcerator in the world. Aboriginal and Torres Strait Islander people represent just 2 per cent of the national population but 27 per cent of the prisoner population and have an imprisonment rate of 2,247 per 100,000 (Australian Bureau of Statistics, 2012).

England and Wales ${ }^{5}$ has been on a clear expansionist penal trajectory since at least the 1970s. Although there was a small reversal in this trend from 1989-1992 when the prison population fell from 50,000 to 41,000, since 1993 the prisoner ADP has increased year on year by an average by 3.7

\footnotetext{
${ }^{5}$ This is also broadly the case for other countries in the United Kingdom.
} 
per cent for nearly twenty years (Berman, 2012). The result is a more than doubling of the ADP of prisoners, which surpassed 80,000 for the first time in December 2006 and reached a record high of 88,179 prisoners on the $2^{\text {nd }}$ December 2011. People categorised as either 'Black or Black British' make up 2.7 per cent of the national population but 13.4 per cent of the prisoner population. 'African Caribbean' women make up 1 per cent of the national population but 24 per cent of women in prison whilst 'African Caribbean' men are eight times more likely to face the sanction of penal incarceration than white men (Sudbury, 2005b; Berman, 2012). Canada, the final Anglophone country considered here, has experienced what may be described as a 'slow creep' towards hyper-incarceration. The prisoner rate in the 1970s and 1980 remained fractionally under 100 per 100,000 although in the last two decades it has consistently exceeded this rate and in 2011 it stood at 117 per 100,000. It is important to note, however, that when data on those admitted to custody is analysed Canada appears not less but more punitive than England and Wales. For example, in 2006 over 232,800 adults were admitted to some form of penal custody; a much higher number than in England and Wales, which is approximately 120,000 people (Webster and Doob, 2007). Whatever the difficulties in comparing prisoner rates Canadian prisons undoubtedly share the same mission to control impoverished BME populations and other members of the 'subproletariat' (Hall, Critcher, Jefferson, Clark and Roberts, 1978). Aboriginal adults make up 4 per cent of the national population but 21 per cent of male prisoners and 30 per cent of female prisoners. In some places such as in Manitoba or Saskatchewan, Aboriginals account for more than for 70 per cent of men and 80 per cent of women sentenced to imprisonment, despite being only 15 per cent of the population. Prisons have always drawn their clientele from the poorest segments of the proletariat but, as the above data indicates, the racist legacy of English colonialism is also clearly evident in prisoner populations across Anglophone nations.

Penal excess and the disproportionate imprisonment of impoverished BME populations are widespread in Western Europe. Spain, France and the Netherlands have all seen record number prisoner populations in the last decade, although Germany has resisted this trend somewhat. Spanish prison populations have sharply increased since the early 1970s: the 2011 prisoner ADP of 73,459 is four times higher than the equivalent figure in 1970 and the enlargement of the prisoner population 
has been particularly marked since the new millennium (Institute of Penitentiaries, 2012). With a prisoner rate of 159 per 100,000, Spain is the highest penal incarcerator in Western Europe and like many other countries in this region, Spain also have a large number of foreign nationals serving long sentences (De Giorgi, 2011, this volume; Walmsley, 2012). The prisoner rate in France has fluctuated considerably (Cavadino and Dignan, 2006). In 1985 for example the prisoner rate was 72 prisoners per 100,000. Within three years the prisoner population increased by over 12,000 to leave a rate of 92 prisoners per 100,000 in 1988 yet by 1990 it had fallen back to 81 prisoners per 100,000. Despite regular amnesties and pardons there is evidence of 'slow creep' in France. ${ }^{6}$ In July 2012 the French prisoner ADP reached a record high of 67, 373 prisoners - a prisoner rate of 101 per 100,000. Although foreign nationals comprised only 6 per cent of the population they accounted for 21 per cent of the prison population.

The Netherlands, once eulogised as a leading example of penal tolerance, has witnessed one of the most dramatic increases in prisoner rates on the planet. In 1973 the Netherlands had a prisoner rate of just 18 per 100,000. By 2005 the prisoner rate had ballooned to 127 per 100,000. ${ }^{7}$ Indeed, of the twelve selected countries, only the USA has experienced a similar escalation in the use of penal incarceration. During this time the proportion of foreign national prisoners grew rapidly rising from 12 per cent in 1981 to 26 per cent in 1992 . Whilst there is some evidence that the Netherlands has turned a corner in terms of penal expansionism, with the prisoner rate declining to 94 by 2010 , in the same year the share of foreign national prisoners rose to 32 per cent. The case of Germany is a little different, at least in terms of rising prisoner populations. Whilst the prisoner population did increase in the latter part of the twentieth century in recent times it has declined. The 2010 figure of 85 per 100,000 had returned to the exact same figure as 1970. Notwithstanding, Germany does not deviate in terms of the over-representation of foreign nationals with 34 per cent of its prisoners designated as

\footnotetext{
${ }^{6}$ The last amnesty law in France was in 2007. The tradition of granting presidential pardons to mark the $14^{\text {th }}$ July celebrations was also ended by President Sarkozy. The recently elected socialist President François Hollande has, so far, refused to sanction any further prisoner amnesties.

${ }^{7}$ The Netherlands include juveniles and other detainees in its official prison rates. The problem of how different detained populations included in the prisoner rates of different countries can make international comparisons difficult is discussed below.
} 
'immigrants' (De Giorgi, 2011). Undoubtedly it is those foreign nationals who face precarious working and living conditions that fill such prisons (Wacquant, 2006, 2010b; De Giorgi, 2011, this volume).

Whereas Anglophone and many Western European countries have indulged in penal excess, for some commentators Nordic countries are places of penal moderation with humane prison conditions (Pratt, 2008a, 2008b, 2011; Pratt and Erickson, 2012). Particular focus in recent years has been on Finland as it is the one country in Europe which has seen a concerted long term decline in prisoner populations. In the early 1950s the imprisonment rate in Finland stood at 200 per 100,000 and even in the 1970s the Finnish incarceration rate remained one of the highest in Europe. It was not until the 1990s that Finland reached a comparative rate with other Nordic countries and in 2010 Finland had a prisoner rate of 59 per 100,000 (Lappi-Seppala, 2012). In contrast to many other European countries Finland also has a low proportion of foreign national prisoners constituting a relatively modest 13 per cent in 2011. ${ }^{8}$ By comparison, Sweden and Norway have experienced 'slow creep' in prisoner rates and have high numbers of (lower working class) foreign nationals behind bars. In the 1950s Sweden had a prisoner rate of 35 per 100,000. This figure had doubled by the 1960s and since the 1970s there has been a gradual increase in prisoner rates. In 2010 Sweden had a prisoner rate of 78 per 100,000 and foreign nationals constituted 28 per cent of the prisoner population (Dullum and Ugelvik, 2012; Walmsley, 2012). 'Slow creep' in Norwegian prisons has also been evident since the mid 1980s. Whilst there have been only modest increases, from for example 56 per 100,000 in 1990 to 73 per 100,000 in 2011, what is most notable is the drastic increase in the number of foreign national prisoner rising from 19 per cent of the prison population in 2007 to 33 per cent by June 2012 (International Centre for Prison Studies, 2012). Though both Norway and Sweden continue to have low populations compared to most other countries in Europe, prisoner rates are not as low as they once were.

\footnotetext{
${ }^{8}$ This approximately the same number of foreign national prisoners as England and Wales in 2012.
} 
Before reaching any firm conclusions some of the problems associated with analysing comparative prison data should be highlighted. Let us first consider the disquiet regarding 'Nordic exceptionalism' (Dullum and Ugelvik, 2012). Concerns have been raised about accepting official data without sufficient consideration of the 'subaltern' voices of prisoners, prisoner collective struggles or alternative 'non-official' sources of information (Jefferson, 2012). Critics note that rates of prisoners per 100,000 of the population may obscure as much as they reveal as: Nordic countries have in the main short sentences but reasonably large numbers of people processed through penal systems (Mathiesen, 2012); that low prisoner rates do not indicate a humane penal system and that rates of self inflicted deaths, which are relatively high in Nordic prisons, may prove more reliable in terms of indicating how prisoners experience penal incarceration (Mathiesen, 2012); that it is impossible to grade pain (Christie, 1981), understand prison conditions outside the wider material conditions pertaining in a society (Neumann, 2012), or remove the inherent harms and pains of penal incarceration (Scott and Codd, 2010); that pre-trail detention and solitary confinement in Nordic nations provide a significant example of inhuman penal practices that are obscured through focus on official quantitative data (Sharff-Smith, 2012). It is important to recognise that the intensification of penal discipline and control that Thomas Mathiesen (1990) highlights is not only about rising prisoner ADP rates.

The above problems regarding data on 'Nordic exceptionalism' are characteristic of general difficulties measuring international prisoner rates (Scott, 2008; Brodeur, 2007 Snacken and Dumortier, 2012). Official 'prisoner rates' are not standardised tools comparing 'like with like'. For a start, not all nations define 'prison' and their populations in the same way: some countries include juvenile offenders and/or those in psychiatric 'care' in penal custody statistics whilst others provide data on adult prisoners only. Finland and Sweden include fifteen to seventeen-year olds in their prisoner rates, whilst the Netherlands include juveniles confined under both the civil and criminal law, resulting in competing estimations depending on which category is included or excluded (Tonry, 2007). In other words, widely different data are available on prisoner rates of the same country for a given year. This makes genuinely accurate measurement impossible. As in the Nordic case, the 
meanings of official prisoner rates are also contested. Measuring the prisoner ADP or prisoner rates may be less accurate at predicting sentencing trends than, for example, measures examining the average days served by prisoners or the relationship between arrests, prosecution and conviction in a given country (Pease, 1994). Though existing official quantitative data on prison populations should not be dismissed out of hand, it should be interpreted with the greatest of care and its limitations duly recognised.

There are also considerable differences in the way comparative data has been analysed. Three broad approaches can be identified: convergence, diversity and context. Theorists of convergence have aimed to highlight globalised socio-economic and political developments in the last four decades that can explain the global penal incarceration binge (Garland, 2001b; Simon, 2007; Wacquant, 2009) or identified particular clusters of nations that represent specific political economic or cultural commonalities (Cavadino and Dignan, 2006; Lacey, 2008; Pratt, 2011). Theorists of diversity have focused on the specific 'risk and protective factors' pertaining in a given nation shaping penal policy and incarceration rates (Tonry, 2007; Green, 2008; Snacken and Dumortier, 2012) or emphasised the manner in which the penal practices of each nation are so deeply embedded within their own history and culture that questions of their 'travels' must be considered very carefully (Melossi, 2011). A third approach recognises distinct national and historical penal practices but contextualises them within a recognition of the intensification of global economic and social inequalities underscoring liberal market and transnational capitalist economies, patriarchies, hetero-normativity and neo-colonial racialised ideologies. This allows for an understanding of diversity between nations alongside recognition of a broader authoritarian drift towards a third historical stage of penal incarceration to control the global poor (Mathiesen, 1990; Sudbury, 2005a; Davis, 2012; Scott, this volume).

Though it would be disingenuous to claim that the official prison data cited above, based as it is on quantitative snap shots of only twelve countries with no reference to rates in Africa, Asia or South America, alone provide incontrovertible evidence of global hyper-incarceration, it does strongly indicate a globalised trend towards an intensification of penal discipline. Prison populations, at 
different speeds in different countries, are in the main growing and they not only contain poor people, but disproportionately poor men and women classified as BME, migrants, refugees, asylum seekers or foreign nationals (De Giorgi, this volume). The question is why?

\section{Questioning incarceration}

The global growth of penal incarceration could be taken to imply that prison has been successful in terms of meeting its stated aims. To some people it may even seem peculiar to ask the question why prison? - surely the answer is self evident - prisons have existed for centuries as places of punishment so there must be a clear, uncontested rationale which explains their introduction, historical development and current expansion. And yet, like exposing an emperor with no clothes, when the apparently obvious reasons for imprisonment are closely examined they are laid bare as a naked sham. Let us briefly, but critically, review five well rehearsed arguments in defence of the prison.

\section{Prisons are a natural and inevitable response to 'crime'?}

No straightforward relationship exists between 'crime' and imprisonment. Prisoners [in most cases] have breached and been prosecuted under the criminal law. This, however, must be understood within the context of the meaning, definition and differential application of the criminal label. 'Crime' is an unstable concept and the diverse sets of behaviours it brings together are united only by the criminal process itself (Hulsman, 1986). Rather than being fixed and constant the meanings and content of 'crime' change depending upon time, place, perpetrator and audience, with the criminal label more likely to be applied if the perpetrator is successfully distanced (Christie, 2004). Selective police surveillance in societies shaped by the determining contexts of capitalism, patriarchies and neocolonialism has resulted in the unequal application of criminal law against socially disadvantaged groups (Sim, Scraton and Gordon, 1987; Barton, Corteen, Scott and Whyte, 2006; Sim, 2009). For as long as we continue to classify and control certain behaviour by certain people using the criminal label, 'crime' will continue to have a relationship to rates of penal incarceration. How they interconnect, however, is extremely complex. 'Crime' and punishment have great symbolic 
resonance detached from actual or perceived rates of illegalities and single criminalised acts can, and do, disproportionately impact on penal policies. A spate of high profile killings or the horrific death of a child is likely in many countries to monopolise media agendas more than mundane but widespread troublesome incidents (Hall et al, 1978; Simon, 2007; Green, 2008; Scott, this volume). Because its definition and application is likely to remain unchallenged, 'crime' can be manipulated to justify authoritarian state interventions without actually increasing in prevalence (Hall et al, 1978; Sim et al, 1987). This indicates that it would be wrong to assume that the main cause of global hyperincarceration is directly linked to rises in recorded 'crime'. Indeed, at times they do not even correlate. Let us consider recorded 'crime' rates in five of the countries highlighted earlier. In the 1990s there were increases in [violent] 'crimes' in the USA, Canada, Germany and Finland. Only in the USA did this result in rapidly escalating rates of penal incarceration. In Germany and Canada the prisoner rate showed only evidence of 'slow creep' or remained reasonably stable whereas numbers actually declined in Finland (Tonry, 2001; Lappi-Seppala, 2012). In England and Wales, after a number of decades in which 'official crime rates' had risen dramatically, 'crime' figures stabilised and then began to decline from 1993. Yet, in the twenty year period since, the prison population has continued to rise without abatement. To dismiss 'crime' entirely from the equation would be a mistake, but there are clearly other reasons why prisons persist and continue to expand.

\section{Prison prevents 'crime' by deterring offenders?}

Popularised by politicians and academics alike under in the slogan that 'prison works' (Murray, 1997) the idea that prisons have a deterrent effect appears almost self-evident. The logic behind deterrence is firmly rooted in the utilitarian calculus that to deter the rational offender requires the pains of imprisonment to outweigh the pleasures derived from 'crime'. Yet the role of prison as a means of deterring 'crime' is vulnerable to critique on a number of grounds; most damningly because most people who refrain from problematic conducts do so for reasons unconnected to the penal law. Moral conscience or family reputations seem to act as the main barriers to wrongdoing for many. On the other hand, people already stigmatised, impoverished and excluded are less likely to fear further stigmatisation through criminal prosecution (Golash, 2005). The very logic of deterrence has also 
been questioned. Most people do not rationalise and calculate costs and benefits about 'crimes'. Further, not only is it actually impossible to determine if deterrence has a positive effect (we cannot measure what does not happen) but what evidence we do have - recidivism rates - overwhelmingly indicates that prison does not prevent 'crime'. In England and Wales, for example, recidivism is high for both young (75 per cent) and adult ex-prisoners (50 per cent), and even here this data only measures those ex-prisoners who both offend and are caught (Scott and Codd, 2010). Indeed prisons not only fail to deter 'crime' but have criminogenic effects, which have surely only escalated in our time of global hyper-incarceration. Thus, rather than controlling 'crime', deterrence may more plausibly be considered as a means of controlling populations (Mathiesen, 1990). For Rusche and Kirchheimer (1939/2003) the value of human life is intimately tied to the current value of human labour and in times of economic instability and financial crisis prisons perform a key role in deterring the poor and marginalised through the principles of lesser eligibility. Unhygienic living conditions and penal servitude send a clear message to the labouring classes that if they do not conform to the rigours of the labour market an even worse fate could yet befall them. This suggestion, however, indicates a more symbolic role for imprisonment shifting attention away from any obvious 'crime'prison link and towards a consideration of political economy (De Giorgi, this volume).

\section{The prison turns bad criminals into good citizens?}

It is often argued that effectively managed prisons can provide an opportunity to reduce the likelihood of re-offending and to 'bring home' prisoner responsibilities. Rehabilitation in recent times has been associated with a treatment model where wrongdoing is conceived as an individual or social disease and, if the problems can be correctly diagnosed, offenders can be cured (Scott and Codd, 2010). Yet 'crime' is not an 'illness' or 'disease' but a social construct and by focusing upon perceived pathologies rooted in individual or social defects, rehabilitation as treatment is profoundly deterministic, denies human agency and moral choices (Scott, 2008, 2009). Treatment programmes individualise 'other' law-breakers as cognitively different whilst at the same time ignore wider problematic social circumstances and structural divisions, such as poverty, sexism, and racism (Kendal, 2002). The pains of incarceration are always more likely to dehabilitate rather than act as a 
conduit for reflection and growth (Mathiesen, 1990). Historically, rehabilitation has also been closely associated with work, penal servitude and discipline (Ibid). Although today in some countries, such as the USA, rehabilitation appears to be little more than mere lip service, in others, as evidenced in penal policy documents such as Breaking the Cycle (Ministry of Justice, 2010) in England and Wales, focus on rehabilitation through work has once again come to prominence. Under this rationale work is considered an essential part of a person's 'normal' activity and an effective means to cure laziness, instil discipline or simply use up time and energy that may otherwise be channelled into lawbreaking (Foucault, 1977). Although prisons are much more likely to create unemployability rather than a skilled reserve army of labour, the political appeal of prisons being perceived as a places of discipline and hard work 'grinding bad men and women good' should not be dismissed out of hand. Indeed, this 'need for discipline' can help explain the authoritarian drift towards hyper-incarceration in many countries around the world.

\section{Prisons protect the public from 'dangerous offenders'?}

Global hyper-incarceration cannot be explained due to rising recorded violent 'crime'. Though in popular mythology prisons contain 'dangerous offenders' who would present a serious future risk to public safety if not imprisoned, all the data indicates that the vast majority of prisoners are not 'dangerous'; at least not when first imprisoned. Prisoners around the globe are generally people with impoverished social backgrounds who suffer from significant health problems and have perpetrated relatively minor property offences (Weiss and South, 1996; Ruggiero, Ryan and Sim, 1996; Scott, 2008). In the USA, which has seen the greatest rise in penal incarceration in the last few decades, more than one million of the prison population have been incarcerated for non-violent offences and the rapid rise in penal incarceration cannot be separated from the increased criminalisation of drug usage in African American communities (Bosworth, 2010; Alexander, 2011). 'Categorical suspicion' (Hudson, 2003) and the control of 'suspect communities' (Hillyard, 1995) is well documented in critical criminological analysis and for some contemporary penality is underscored by the logic of actuarialism (Simon, 1987; De Giorgi, 2011). Actuarialism entails the systematic analysis of the statistical distribution of criminal behaviours in a given population where criminalisation is closely 
linked to the group to which the offender belongs rather than the actual offence committed. Its effectiveness is dependent upon the aggregation of criminal characteristics and the subsequent use of techniques to identify those who most closely fit criminal risk profiles. This entirely removes individuals from the 'crime' control equation (Simon, 1987). Such a rationale sees the end of the acknowledgement of 'false positives' (people wrongly predicted to offend in the future) as now the criteria of accuracy is judged solely on the correspondence between risk profiles and individual characteristics. Grounded in positivism and risk assessments, this approach is philosophically untenable because quite frankly we do not have the ability to accurately predict who will commit [serious] offences in the future (Mathiesen, 1990). Braithwaite and Pettit (1990) claim that even the best prediction techniques are wrong at least twice as often as they are right, whilst Deidre Golash (2005) estimates that predictions are generally wrong eight times out of nine. Prisons are not filled to the brim with dangerous offenders but rather with lower working class, BME, migrant and foreign national lawbreakers. What does remains plausible after such revelations is an analysis of advanced capitalist, neo-colonial, patriarchal and heteronormative societies that identifies the prison as performing an important role in maintaining economic and social inequalities through the selective incapacitation of the 'detritus and the damned' (Mathiesen, 1990; Davis, 2012; Meiners, this volume; Cooper and Sim, this volume).

\section{5. $\quad$ Prison reflects our need to punish 'crime'.}

Penal incarceration appears so deeply entrenched in our cultural sensibilities that prison and punishment have become almost synonymous (Melossi and Pavarini, 1981). It has long been recognised that punishment may be intended as a moral message to denounce 'crime' with its severity reflecting collective indignation and revulsion (Durkheim, 1893/1984). The effect and intent of the expressive and symbolic role of incarceration are open to debate but there are concerns that the penal obesity of the last four decades has so far failed to satisfy appetites for penal destruction. For some commentators populist punitiveness drives contemporary penal excess with its power being directly connected to the weakening of state bureaucracies and the rise in political influence of an unredeemable mob demanding longer and harsher sentences (Pratt, 2007). Evidence to support this 
assertion is a little thin on the ground; those studies that have investigated public opinions on punishment indicates that when people are well informed they are considerably less punitive than public opinion polls suggest (Green, 2008). More sophisticated accounts have laid the problem of penal excess and the penalisation of sites of state detention at the door of increasing economic and social inequalities and weakening social solidarities (de Haan, 1990; Christie, 2000; Bosworth, 2010) or explored the ways in which fears and anxieties concerning 'crime' have been deliberately orchestrated from above to shift attention away from the real problems in society (Hall et al, 1978; Beckett, 1997; Simon, 2007; Sim, 2009; Bell, this volume). It is also questionable whether the demand for the infliction of pain and suffering is healthy, as the venom of punishment is poisonous for all it encounters. It is unlikely that suffering can expiate guilt or provide a good way of restoring relationships and punishment is not a very effective means of moral communication (Mathiesen, 1990). Few would doubt that some kind of response is required for many of those behaviours currently defined as 'crimes' but there is no obvious reason why this should be imprisonment. Two wrongs can never make a right. We do not need to punish - alternative and rational means of redress and conflict resolution are feasible within the immanent possibilities of our times (de Haan, 1990; Scott, this volume). The more brutal we are to those who do wrong or have unpleasant, unattractive and disturbing behaviours, the greater the acceptance of cruelty, the weaker the sensitivity to pain. Punitive societies are callous and morally indifferent to the suffering of others. Consequently the current global expansion of incarceration must be problematised and its targeting of the poor and BME populations exposed.

\section{Structure of the Book}

When 'common sense' assumptions and justifications of imprisonment are subjected to serious critical scrutiny the prison appears to have no straightforward or obvious defence (Mathiesen, 1990; Golash, 2005; Scott, 2009). Despite the 'fiasco of its aims' (Mathiesen, 1990) abolitionist analysis of penal incarceration remains relatively marginalised in the academy and often politically delegitimated. Indeed, rather than being in terminal decline prison populations in countries all around the world have risen to unprecedented levels. This phenomenon demands serious academic attention 
and in recent years the study of imprisonment has undergone a period of great creativity, which is reflected in the chapters brought together in this book. Though for Armstrong and McAra, (2006:22) contemporary critical analysis should aim to 'decentre the prison without dismissing it' arguably it seems more pertinent to ask why prison continues to perform such a central role in both the public imagination and social control of deviant populations. It is important therefore that the why prison? question is posed in an intellectually honest and rigorous manner. As Keally McBride (this volume) points out, questions concerning imprisonment today merely concern 'how can we justify incarceration', 'what does prison do to those confined' or 'who should be imprisoned' rather than going back to the most fundamental question of all: why should prisons exist? Although the why prison? question can be approached in a number of different ways, for the purpose of this book contributors have focussed upon one or more of its following interconnected meanings:

1. Why does the prison continue to persist when there is so much evidence that it fails?

2. Why is the prison so deeply ingrained in popular culture and so widely considered as the most appropriate response to law-breaking?

3. Why are we witnessing the penal colonisation of other sites of state detention and the rise of global prison populations at such an alarming rate?

The first three contributors, Alessandro De Giorgi, Emma Bell and Loïc Wacquant scrutinise the prisons role in disciplining and controlling certain segments of the working class. In chapter two Alessandro De Giorgi argues that in our late-capitalist 'wastelands of insecurity' we are witnessing the unleashing of the penal arm of capitalist states to govern the new global proletariat of working poor. Underscored by the principles of less eligibility, the prison is designed to deter 'the most marginal factors of the proletarian class form turning to 'crimes of survival' as a form of resistance to waged labour'. Throughout the chapter he points to the need for an analytical framework that can recognise how and why the logic of penalisation stretches beyond the prison to encapsulate immigration controls, welfare regulation and broader 'processes of excommunication' of poor and migrant populations. After evidencing the hyper-criminalisation of immigrants in the Europe, 
Alessandro De Giorgi lays down the foundations of a new 'cultural political economy of punishment' that can transcend the traditions narrow focus on unemployment to conceptualise and problematise the economic and social structures of late-capitalist societies and their implications for the regulation of the global working poor. In a similar vein Emma Bell examines the rise of 'egotistic individualism' (Reiner, 2007) and recent developments in penal policy in Britain in chapter three. Identifying the current Conservative-Liberal Democrat coalition government as a contemporary manifestation of 'authoritarian populism' (Hall, 1988), she revisits Thomas Mathiesen's (1990) 'unofficial aims of imprisonment' to explore their contemporary role in constructing symbolical boundaries and diverting attention away from increasingly stark social divisions. The penalisation of poverty is understood within the 'paradoxical' nature of public opinion and the rise of the 'security-industrial complex'. After discussing the so-called rehabilitation revolution and the interconnections between penal privatisation, penal labour and immigration controls, Emma Bell concludes her chapter by emphasising the continued symbolic potency of penal incarceration.

Reflecting upon his recent book Punishing the Poor, Loïc Wacquant argues in chapter four that hyper-incarceration must be understood as a political response to the social insecurities arising due to changes in labour markets and a backlash against greater racial equality. Inspired by the work of Pierre Bourdieu, and especially his notion of the 'bureaucratic field', the chapter identifies the restrictive turn from social welfare to workfare. Loïc Wacquant argues that the expansive cast of penal policies are two sides of a broader revamping of state policy towards 'problem categories and territories' which are united under the same 'behaviourist philosophy'. The prison consequently partakes in the reengineering of the state and serves two key functions: the containment of an emergent regime of 'advanced marginality' and a signalling of the authority of rules at a time when state sovereignty is being eroded from above by capital mobility and from below by the diffusion of social insecurity. In so doing he carefully weaves together the symbolic-materialist and instrumentalexpressive divide that has characterised the sociology of punishment since the early interventions of Emile Durkheim and Marxist penologists such as George Rusche. As such Loïc Wacquant not only explores why prisons are central to the overall workings of the contemporary capitalist state but 
provides a clear warning that the containment of unwanted and impoverished populations by the 'penal state' represents a significant danger to the workings of democracy itself.

Magnus Hörnqvist, Michelle Brown and Vanessa Barker explore the cultural embeddness of penal incarceration through analysis of participation in penal practices and penal policy formation. Chapter five provides an innovative analysis of why middle class professionals work in penal bureaucracies. Posing this question within the context of both the 'invisibility' of the professional middle classes in the sociology of punishment and the apparent little obvious benefit gained by participating in the internal workings of the penal machine, Magnus Hörnqvist carefully considers 'how the professional middle class constitutes itself as a class in and through the desires, fears and fantasies played out within the institutional domain of the prison'. Drawing upon the insights of Pierre Bourdieu and Jacques Lacan, and utilising a number of examples from Swedish prisons, Magnus Hörnqvist reveals that not only are prisons places of 'pacification' facilitating social order and suppressing fear, but also represent/create a unique environment facilitating engagement in both the pleasures and fantasies of violence and mundane humanitarian interventions - all done, of course, for the higher interests of the state.

Michelle Brown shines the spotlight on the negative consequences of public distance from penal processes in chapter six. Whereas the punished live through the brutal realities of penal incarceration, the penal spectator is shielded from the pains of confinement by 'experiential distance'. Despite widespread prison talk the realities of penal incarceration remain largely inaccessible to white middle class bystanders. Consequently, the cultural imaginary of the prison via media representations in TV dramas, documentaries and iconic films, alongside more direct physical engagement in prison tourism, become crucial in shaping public knowledge. Yet a little knowledge can sometimes be a bad thing, for the penal spectator is not required to give more than a 'distant look or fleeting glance' at the tragic quality of penal incarceration - the deliberate infliction of pain and suffering. It is not just the failure to break down emotional distance that is of concern but also the fact that the penal spectator 
assumes he/she is now fully informed. Of central importance then are strategies that can find 'a way out' by publically exposing prisons for what they really are.

In chapter seven Vanessa Barker starts by locating penal excess and welfare retrenchment within a breakdown of American democracy and specifically the decline of public participation within the public sphere. For Vanessa Barker imprisonment is inherently political - engendering state authority, the power to punish and the moral legitimacy of pain infliction - alongside possessing a powerful symbolic function. She argues that de-democratisation can lead directly to penal excess as weakened social bonds result in greater political rigidity and entrenched political positions. In contrast however, more democracy can reduce penal excess as civic engagement is a form of collective agency and can be expressed through 'deliberative forms' of participation. Greater public participation, she maintains, results in enhanced engagement with pressing social issues and consequently more empathy, solidarity, trust and calls for welfare interventions to social problems.

The next three chapters by Mark Brown; Emma Kauffman and Mary Bosworth; and Vickie Cooper and Joe Sim examine in depth the relationship between imprisonment and other sites of state detention. In chapter eight Mark Brown argues that a singular focus on imprisonment has been detrimental to the broader understanding of confinement and what is urgently required is a new way of thinking that can once and for all escape the 'iron cage of prison studies'. To free ourselves from such an intellectual straightjacket, we should investigate the prison as merely one form of 'involuntary detention'. Mark Brown outlines a theoretical rationale for such an analytical break and then asks the crucially important question 'why does it seem so much more suitable that a detention centre should look and feel like a prison, rather than, for example, a hospital or aged-care village'. His arguments are illustrated through a consideration of a number of different contemporary sites of state detention: non-penal preventive detention derived from civil laws; 'slave like' immigration detention; and the control of terror suspects, migrants and refugees through the creation of 'international zones'. He then proceeds to construct a new way of conceptualising 'prison-like forms' through a re-articulation of existing criminological thought. 
Chapter nine by Emma Kaufman and Mary Bosworth examines the hypothesis that prison and immigration detention perform a central role in the [re]production of the nation state. Identifying a major escalation in the control of 'non-citizens' in Britain since the mid 1990s, they explore the emergence of a symbiotic relationship between these two forms of state detention. Whilst still recognising that prison and immigration detention are distinct entities, they point to their similar mission to classify and contain those 'non citizens' who should be excluded in the interests of national sovereignty. Acknowledging the historical connections between the two forms of confinement, Emma Kaufman and Mary Bosworth utilise ethnographic research to evidence how detainees experience Immigration Removal Centres as equivalent to or even worse than prison. Vickie Cooper and Joe Sim explore the convergence of penal and welfare institutions in the governance of the homeless in Liverpool in chapter ten. 'Locked out, locked up and quarantined', the homeless in Liverpool are regulated by 'processes of punishment' where disciplinary penal and welfare logics are deployed to reconstruct, rebuild and re-programme 'deviant subjectivities'. Exploring findings from an ethnographic study of homeless women in Liverpool, Vickie Cooper and Joe Sim highlight how the boundaries between penal and semi-penal institutions have become increasingly blurred. Emphasising how violence underpins state practices, they explore why attempts to normalise homeless and other petty offenders have merely proved to be 'debilitating and disempowering'. Vickie Cooper and Joe Sim conclude by calling for the need for more 'utopian, socialist and abolitionist' strategies that can transcend the punitive ideologies and practices of the capitalist state.

The following two chapters by Keally McBride and Marie Gottschalk both reflect upon whether progressive penal reform can result from current pressures to reduce penal expenditure in the USA. Keally McBride argues in chapter eleven that since the 1970s the assumption has been that people cannot be changed through imprisonment, therefore they should remain in prison for as long as possible. After exploring the deeply entrenched political desire to incapacitate those who fail to live their lives as 'economically driven creatures', she argues that because of the 'great recession' crime talk is increasingly becoming about 'balancing budgets' and being 'tough on crime and tough on 
criminal justice spending'. Indeed such are the consequences of the fiscal crisis, such as in the state of California, that today the logic of economic rationality may have become useful for those calling for radical reductions in prisoner populations. In chapter twelve Marie Gottschalk highlights how the political agendas of four social movements in the USA have been exploited or manipulated by government organisations and law enforcement groups to ratchet up penalisation. The retributive victims' rights movement has been grounded in a 'zero-sum game predicated on tougher penalties for offenders'; the women's movement has made problematic alliances with the punitive lobby, fostering a reductive analysis of gendered violence as individual pathology; the prisoners' rights movement created a 'racially charged political atmosphere' leading to a backlash from conservatives and a lockdown on political activism behind bars; and the campaign to abolish capital punishment has brought 'popular sentiments and passions' to the forefront of the formation of penal policy and undermined more rational and objective debate. Throughout Maria Gottschalk emphasises the complex interrelationship between social, economic and political dimensions and argues that 'ghosts of the past' cannot be exercised alone by the economic impact of the great recession - what we require in our troubled economic times is the mobilisation of progressive social movements that can generate and exploit political momentum in the direction of [radical] penal reduction.

Penal abolitionism as a social movement and analytical framework is explored in the final three chapters of book by Erica Meiners, Julia Oparah and David Scott. In chapter thirteen Erica Meiners critically examines the relationship between the school and the prison in the USA, emphasising the role public education performs in the surveillance, discipline and control of children of colour and non-heterosexual youth. She emphasises how the 'logic of punishment' increasingly shapes the policy, ideology and practice of public schools which have begun to 'look and act a lot like detention centres'. For Erica Meiners to escape from the 'prison industrial complex' and its collateral consequences we need to abandon existing categorisations of childhood and develop a new way of thinking that can allow for the recognition of a [young] persons shared humanity. She argues that penal reform may simply extend the carceral mesh and so what is required is the adoption of an abolitionist vision which can decolonise the punitive rationale lying at the heart of contemporary 
schooling practices in the USA. Julia Oparah in chapter fourteen asks the essential question Why No Prisons? Her chapter is organised around five key themes: prison is a descendant of slavery; prison increases fears rather than providing safety; prison spending channels funds away from education, health and social welfare; prisons damage democracy; prisons reproduce violence and provide no protection from violence perpetrated in the community. Julia Oparah argues that in sum these five strategies reinforce the claim that the only rational response to the prison-industrial complex is abolition. She concludes by identifying a number of progressive social policies that could be promoted immediately to challenge penal incarceration and provide genuine safety for all.

Bringing the book to a close, David Scott argues that prisons are 'unequalled in pain' in chapter fifteen. This final chapter begins by highlighting the raison d'être of penal incarceration: the deliberate infliction of pain and the allocation of blame. The discussion then places global hyperincarceration within the contexts of mounting economic inequalities and the social inequalities of class, 'race', gender and sexuality. Focusing upon England and Wales as an illustrative example, the chapter identifies a number of factors driving the intensification of penal logic in advanced capitalist, patriarchal, neo-colonial and hetero-normative societies. The chapter then attempts to answer the question what can we do right now to reverse global hyper-incarceration? from an 'abolitionist real utopia' perspective. In so doing David Scott highlights a number of historically immanent alternatives to penalisation; emphasises the strategic importance of the 'attrition model in reducing prison populations; and calls for more collective resistance against global hyper-incarceration though abolitionist inspired social movements. 